\title{
Communication Experiences and Challenges of Kindergarten and Elementary Teachers in Online Learning during the COVID-19 Pandemic
}

\author{
http://dx.doi.org/10.25008/jkiski.v6i2.582 \\ Sri Seti Indriani ${ }^{1^{*}}$, Ditha Prasanti ${ }^{2}$ \\ ${ }^{1,2}$ Faculty of Communication, Universitas Padjadjaran \\ J1. Raya Ir. Sukarno KM 21, Jatinangor, Kabupaten Sumedang 45363 - Indonesia \\ *Corresponding author: seti@unpad.ac.id
}

Submitted: August 12, 2021, Revised: September 18, 2021, Accepted: December 09, 2021

Accredited by Kemristekdikti No. 28/E/KPT/2019

\begin{abstract}
The increasing number of patients recovering from the COVID-19 and the decreasing number of people exposed to the infection seemed to raise the community's hopes for returning to face-to-face learning. Some schools have slowly implemented face-to-face learning. Teachers sincerely hope to optimize face-to-face learning soon. However, there are still pros and cons over face-to-face learning for fear of schools turning into COVID-19 clusters. The teachers complained about various online learning problems, so they applied for permission to conduct face-to-face learning. The purpose of this research is to understand teachers' experiences in online learning during the COVID-19 pandemic, including positive and negative experiences as well as obstacles in the online learning during the pandemic. This study uses descriptive qualitative research methods, with data collection technique conducted through documentation studies as well as interviews with five kindergarten and elementary school teachers. The selection of research subjects used purposive sampling. The results of this study revealed that the teachers had extraordinary experiences, both negative and positive. The negative experiences during online learning are related to confusion, culture shock, dissatisfaction, stress, fatigue, and overwhelm, while the positive experiences are related to the ease of attending meetings simultaneously, carrying out activities at home and gaining new knowledge, especially in communication technology. Barriers and challenges experienced by teachers in online learning during the pandemic are technical and nontechnical in nature.
\end{abstract}

Keywords: Experience of kindergarten; communication barriers; teachers; pandemic Covid-19; online learning

\section{Introduction}

Almost two years ago after COVID-19 was for the first time declared a pandemic, many still cast doubt on whether schools should immediately implement blended learning. Blended learning is an alternative model of offline and online learning in elementary schools. The doubt over blended learning is due to uncertainty about whether it is safe to live with COVID-19 or there will be a spike in COVID-19 cases. Despite the improving recovery rate of COVID-19 patients, the number of active cases and deaths was still high.

The increase in the number of patients recovering from COVID-19 raised hopes for 
the community to immediately return to faceto-face learning, while on the other hand health procedures and protocols were still under discussion. Therefore, the Secretary of Bandung City Government and the Executive Chairman of the Bandung City Covid-19 Handling Task Force, Ema Sumarna, ensured that limited face-to-face learning (PTM) in Bandung City would be resumed in the second week of September 2021 (Perdana, 2021). A total of 1,600 schools, ranging from kindergarten (TK) to senior high school (SMA) reopened limited classes (Susanti, 2021).This transition process is certainly not easy since the in-person learning must be conducted under strict health protocols. The other reason is that some students have been accustomed to online learning.

A research conducted by Jamaluddin shows that $60 \%$ of the students surveyed were used to online learning, and $50 \%$ of them stated that the system facilitated the learning and mentoring process in certain situations and conditions (Jamaluddin et al., 2020). This statement is interesting since many teachers and students have earlier complained about online learning and wanted to return to offline learning soon during the pandemic.

Most researches find obstacles and challenges in online learning, ranging from internal, external, technical to non-technical problems. The lack of knowledge about the use of technology and a large amount of expenditures pose obstacles to the learning process (Mastura \& Santaria, 2020). However, on the one hand, this exposure makes both teachers and students learn various technologies and eventually master the technologies little by little.

The main problem in the implementation of learning lies in the network. Network strength has always been a problem that reduces learning effectiveness (Harahap et al., 2021). Network problems that were initially a matter of concern have now become common and are understood. Parents who play an essential role in guiding their children in this learning process (Mastura \& Santaria, 2020) are not immune to various problems. Syarifudin (2020), in his research, revealed that $67 \%$ of students had problems with internet access when studying online during the Covid-19 pandemic as concluded in the Lentera Pustaka TBM survey.

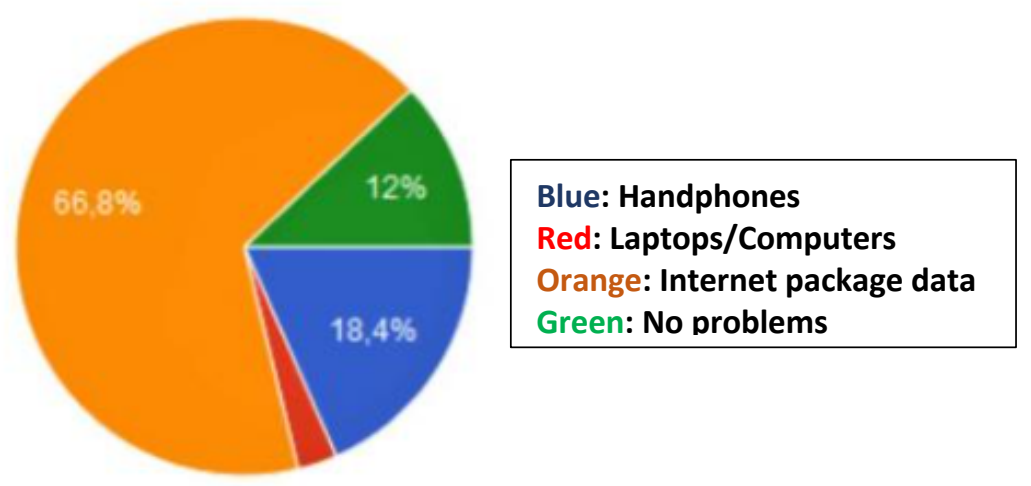

Figure 1. Students' Online Learning Problems Faced by Mothers

Source: Survei PJJ TBM Lentera Pustaka, www.Indonesiana.Id, n.d.

The description above emphasizes some of the problems that exist during the online learning. However, this pandemic has not been able to restore the offline learning period fully as before. There are concerns that the blended learning will be stopped again if positive cases of COVID-19 rise again. Even though online learning is an effective solution to activate classrooms, teachers and students are getting accustomed to online learning. However, it is critical to evaluate this learning technique according to local conditions, on account of the distribution of facilities and the ability of parents to provide different online learning facilities to students in Indonesia (Herliandry et al., 2020)Therefore, this study aims to reemphasize the importance of face-to-face learning by looking at teachers' experiences over the last two years. Teachers' concerns and feelings are described holistically using qualitative research methods. 
This research aims to understand teachers' experiences in online learning during the pandemic. These are some research questions: (1) What are the positive and negative experiences of teachers in online learning during the pandemic?; (2) What are the obstacles experienced by teachers in online learning during the pandemic?

\section{Theoretical Framework}

Online learning is something that is not planned. However, it has often been shown and discussed before the Covid19 pandemic. Online learning is one of the hallmarks of the revolution in which a large amount of human labour is replaced by technology, and the connection with this research is with computers. The world of education certainly has its challenges in responding to these changes (Cholily et al., 2019).

Online learning commenced in March 2019 in all schools, ranging from Kindergarten to Institute of Higher Learning. Research conducted at senior high school SMA Negeri Gabus shows that during the COVID-19 pandemic, online learning took place by providing mentoring or teacher guidance. However, the implementation of online learning caused many problems (Dewi \& Sadjiarto, 2021). It is found that the students (Hidayat et al. 1 (2020), were not quite ready for online learning. This was caused by study habits and lack of technological support (Hidayat et al., 2020).

The students have new problems with discipline. They were less disciplined with time and some of them complained about. the teachers who should be the primary facilitator alternative to parents (Mastura \& Santaria, 2020). This indiscipline is the result of students' declining interest in learning. They felt bored because they did not meet their friends and teachers directly (Yunitasari \& Hanifah, 2020).

\section{Communication Barriers}

The obstacles to online learning are part of communication barriers. Communication barriers are anything that hinders the effectiveness of delivering and receiving messages between communicants and communicators. However, it is really impossible for someone to communicate effectively. In interpersonal communication, there are several types of barriers. These barriers can arise at any time during communication. There are four commonly encountered barriers: physical barriers, physiological barriers, psychological barriers, and semantic barriers (DeVito, 2009).

Physical barriers are related to the environment in which these communicators are communicating, situation, conditions, and atmosphere. Physiological barriers are related to the physical condition of the communicators, whether because they cannot hear well or not. Psychological barriers are related to the state of psychologist communicators. Are they able to concentrate on exchanging messages, or is there something psychological that is bothering their minds? Finally, semantic barriers are related to the existence of misperceptions that occur.

What about barriers related to media? During this pandemic, research on communication barriers highlights communication saturation, limited interpersonal communication, and limited space and time in learning activities. It was also found that there has been a decline in students' self-confidence and the emergence of feelings of loneliness. Limited access to technology, information, and literacy has also become a problem (Emelia \& Arina, 2021).

Limited access to technology and information poses an obstacle which was often found in the previous researches. The discussion that is usually carried out in person is not always practical because not all students have the same technological skills, weak signals make it difficult to find a good internet connection, and some have limited credits.

\section{Computer-mediated communication (CMC)}

The process of online or distance learning using media is inseparable from the theory of computer-mediated communication (CMC). This theory essentially explains how communication occurs, which is mediated by digital technology. CMC is always associated with online internet communication ((Littlejohn \& Foss, 2009). This theory emphasizes that communication between users is not just information or entertainment. So, there is an interactive nature between users. This theory is relevant to this research because it looks at teachers' experiences in the communication process with their students or parents of students through various media.

In this case, the media platforms that are often used are Zoom and WhatsApp for 
communicating learning materials. In addition, smartphones are used for sending and receiving email, or even downloading or uploading songs, pictures, or videos. They also use chat systems, world wide web (www), textual systems, graphics, photography, audio, hyperlinks, social networking systems and friendship search systems such as Facebook, which can be categorized as CMC (Arnus, 2018). The interactivity that occurs is between teachers, students and parents. This interactivity is one of the crucial elements in this theory. Online interactivity is distributed across the network and cannot be reduced to several point-to-point exchanges. Each message considers the previous message and the way the previous messages react to each other (Littlejohn \& Foss, 2009).

In several previous studies, CMC is said to be less effective in learning that requires direct practice. According to Marani et al. (2020), this is due to three main factors, namely internal, external and contextual factors. External factors are related to time, family, lack of support from the surrounding environment and financial problems. Internal factors are related to students' ability to manage their time. Contextual factors are more related to online applications that are less friendly and less interactive for users (Marani et al., 2020).

\section{Material and Methodology}

This study uses descriptive qualitative research methods. Qualitative research methods are commonly used in various research disciplines, ranging from education, psychology to social sciences. The use of the methods is not only to explore the complexities of the experiences and challenges of teachers during the pandemic but also to explore and understand more deeply and holistically the teachers' experiences.

The term descriptive research refers to the types of research questions, designs, and data analysis applied to a particular topic. Descriptions emerge after creative exploration and serve to organize findings to match explanations. Descriptive methods usually explore a group of people, an object, a set of conditions, a system of thought, or a class of events at present. This descriptive method aims to make a systematic, factual and accurate description, description of the phenomenon under study.

The terms qualitative research and descriptive research are sometimes used interchangeably. However, a distinction can be made between the two. One of the fundamental characteristics of these two types of research is that they involve actual data. They try to see experiences that occur naturally without intervention or manipulation of variables (Nassaji, 2015).

This study covered five kindergarten and elementary school teachers. The selection of research subjects used the purposive sampling method. Sampling in qualitative and quantitative research is very different, as it aims to gain a deep understanding of the phenomenon under investigation rather than generalizing the results. The selection of participants in qualitative research is carried out to extract a maximum of information about the phenomenon under study. (Hadi et al., 2012).

Purposive sampling, or selective sampling, is a technique used by qualitative researchers to recruit participants who can provide in-depth and detailed information about the phenomenon being investigated. The purposive sampling technique was chosen because not all samples had criteria that matched the phenomenon under study. Therefore, the researchers chose the purposive sampling technique to determine specific considerations or criteria that the samples used in this study had to be met.

The criteria of informants used in this study: (1) The informant is a teacher who teaches at the kindergarten level to the sixth grade of elementary school, (2) The informant has taught for at least two years. (3) The informant is a teacher who actively teaches online.

Table 1. Research Informants

\begin{tabular}{clcc}
\hline No. & Informants & Years of Teaching & Initials \\
\hline 1 & $2^{\text {nd }}$ grade teacher & 14 & $\mathrm{G} 1$ \\
2 & $3^{\text {rd }}$ grade teacher & 10 & $\mathrm{G} 2$ \\
3 & Kindergarten teacher & 2 & $\mathrm{G} 3$ \\
4 & $3^{\text {rd }}$ grade teacher & 6 & $\mathrm{G} 4$ \\
5 & $6^{\text {th }}$ grade teacher & 2 & $\mathrm{G} 5$ \\
\hline
\end{tabular}


(Source: Result of Research, 2021)

G1 is a 2nd-grade elementary school teacher who teaches almost all lessons such as mathematics, fiqh and thematics. G2 teaches at Madrasah Ibtidaiyah Nurul Falah and has been teaching for 14 years. G2 is a third-grade elementary school teacher and teaches thematic and Islamic religious lessons. G3 is a kindergarten teacher who has experience in teaching children for five to six years. G4 is a third-grade teacher who has been teaching for approximately six years. G5 is a sixth-grade elementary school teacher who has an additional challenge as sixth graders during transition to high school.

This interview was carried out online and offline. Three of the informants used video conferencing platform Zoom, one used social messaging platform WhatsApp and the other two informants were interviewed offline. Indepth interviews were conducted to get the overall experiences of the informants in online learning during the pandemic.

\section{Result and Discussion}

During the COVID-19 pandemic, starting in March 2020, schools in Indonesia shifted from face-to-face to online learning. This extraordinary event was simultaneously practiced throughout Indonesia. The Minister of Education and Culture emphasized that online/distance learning is carried out to provide a meaningful learning experience for students without being burdened with the demands of completing all curriculum achievements for grade promotion and graduation (kemdikbud, 2020).

The results of this study found experiences including those recognized as extraordinary experiences accompanied by obstacles and challenges in teaching. Therefore, the results and discussion of this research are presented by first discussing the informants' experiences and then the obstacles and challenges they face during this pandemic.

\section{Teacher's experience in the online learning process}

All informants admitted that this extraordinary experience was never thought of before and was a sudden shock that it took a long time for them to adapt. They were confused in the early weeks of the pandemic, not knowing what to do and how to teach. At first, all the teachers thought that this online learning would only be temporary to last for two weeks. Nevertheless, beyond their expectations, online learning was continuously being extended from one ministry announcement to another.

Three of the informants, when interviewed, seemed depressed under the condition of the online learning process. They expressed their complaints that they had kept hidden. G1 said that this was an extraordinary experience, 'sesuatu banget', because the pandemic was beyond imagination. G1 said there were more sorrows than joys because no teachers were prepared for this. There was a 'culture shock' that was suddenly experienced without preparation. This culture shock experience occurred because they were prepared only to teach with offline learning models during their lectures.

Maizan et al. (2020) said that changing conventional habits into technology-based activities can bring the people involved in experiencing culture shock. The implementation of learning activities during the pandemic came a surprise because it spontaneously migrated to online learning (Fahmi, 2020) Cultural changes are visible, starting from the communication ethics they usually use to a teaching culture that is much different from face-to-face learning. The ethics of communication usually carried out between individuals seems lost, and computer-mediated communication ethics are needed.

Dissatisfaction was expressed by G2, because the learning materials were not conveyed thoroughly, both in particular and in general. Another thing that made them dissatisfied was that they could not meet with children physically. As a result, the bond between teachers and students seems to be lost, and there is no positive relationship bonding. A positive relationship between teacher and student influences the student's academic success, avoids problematic behaviour or mental problems and helps character growth inside and outside the classroom (Bajpai, 2021)This is in line with previous research findings, which emphasized restrictions on communication between individuals as an essential barrier (Emelia \& Arina, 2021). Qualities such as mutual trust, mutual respect, 
and mutual love decrease when learning is done online.

Students' behaviour and mental problems also cannot be monitored to the fullest. In research conducted along with university students, students experience symptoms of academic stress that affect their physical, emotional, behavioural, and mental states. Stress emerged from problems that occurred from within (internal) as well as in the environment and circumstances (external) (TOctasya \& Munawaroh, 2021). This stress is experienced by students and teachers who are overwhelmed by change and are forced to adapt immediately.

G3's experience received while teaching in kindergarten during the pandemic was described as tiring. This claim was because a teacher is required to continue to be creative and innovative, especially for students who are in kindergarten. Besides complaining about this experience, G3 also said that sometimes she felt overwhelmed when she had to be ready to serve the students at all times. G1 stated that she must always be ready to answer students and their parents round the clock in her capacity as a teacher.

This is certainly very different from the offline learning, in which if teachers and parents want to communicate, they first set time to meet at school. This situation is similar to the research conducted by Purwanto, who said that teachers had unlimited working hours during this pandemic because they had to communicate and coordinate with students, parents, other teachers, and school principals (Purwanto et al., 2020).

Another tiring experience is when teachers have to partake in all events simultaneously, such as attending two zoom events at once. Of course, they cannot follow optimally the materials presented in the two events. . As said by G1, teachers, in addition to teaching, are also required to attend school meetings, seminars and training. This training mostly concerned online teaching training. On the one hand, this experience is a positive thing because they feel convenient to participate in more than one Zoom activity, listening to one Zoom event while following the other. On the other hand, teachers can attend several meetings at once, so they do not miss specific information. However, they cannot 100 per cent focus on any one material.
The most challenging experience is when the teachers had to rack their brains to be creative so that their students did not get bored. They also had to make learning atmosphere exciting and fun. Some students complained that virtual learning was boring since there is no interaction that made them feel the learning atmosphere.

Experiences were not only about 'unpleasant' thing but also on pleasant thing.. The first funny experience was that the learning process could be done at home. Teachers who have children did not need to leave their children and could do other activities at home. Unlike in the pre-pandemic period, married teachers who have children need to leave their children for most of the day.

Positive and helpful experiences were that teachers learned many new things, such as interactive applications facilitating the learning process. For example, they can learn how to create and edit a video. In addition, these applications can increase students' attention to certain materials.

Based on the teachers' experiences above, putting aside happy and positive experiences, teachers are required to be ready all day long to answer questions related to assignments and lessons via social media (WhatApp) platform from both students and parents. Regarding time, teachers are required to always be present at meetings, seminars, and training simultaneously. Teachers are required to be creative, so they have to learn new technology applications, and this requires a long time and process to make a video lesson. Teachers are also required to check far more assignments than in offline learning. These things result in an overwhelming experience. The changes cause stress, which indirectly affects teaching quality and emotional exhaustion (Collie, 2021). This fatigue and exhaustion made the informants worry, both for themselves and their students.

From the description above, researchers created a teacher experience model during the pandemic. This experience model illustrates how teachers experience these difficult times. The previous research mostly focused on students. Both teachers and students experienced the problem of being overwhelmed and fatigued in a balanced way. 


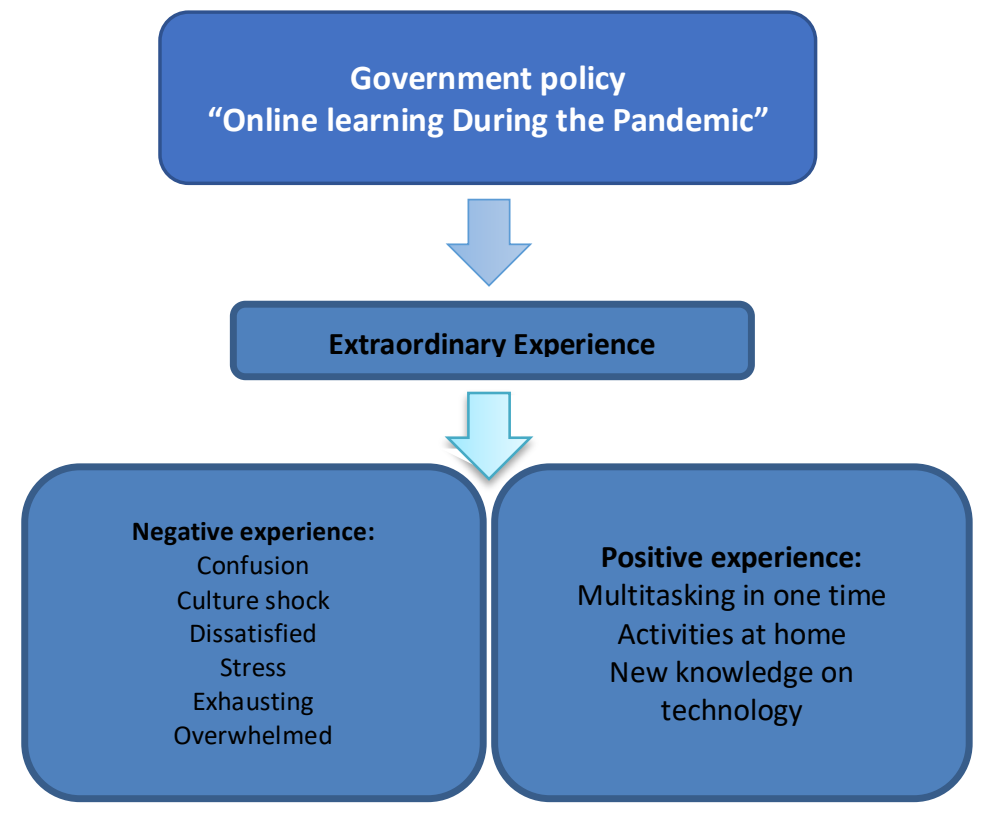

Picture 2. Model of Teachers' Experiences during the Pandemic (Source: Processed research data, 2021)

Teacher Barriers and Difficulties in the Learning process

This research found that the obstacles and difficulties faced by teachers in the learning process were divided into technical and nontechnical matters. Non-technical barriers are related to students' questions and answers in asking things they do not understand. For example, one student asked at one time and another student at another time, while the questions could not be repeated. The answers they received were difficult to understand via WhatsApp because there was no direct interaction. The absence of direct interaction creates many limitations in the learning process, especially in answering the questions the students asked.

Regarding the media used by these teachers, they mainly chose WhatsApp in communication. The WhatsApp application is the first choice used by the teachers. Furthermore, $15 \%$ of the teachers use several WhatsApp supporting applications such as Google Class, Google, YouTube and short videos related to the materials taught in 10-20 minute class. The following application is Zoom Cloud Meeting (Anugrahana, 2020).

The next non-technical obstacle is when the teachers experienced stagnation or 'got 'stuck' in their creative ideas. When they have creative ideas, they then remember the limitations of media and need parental cooperation. In the end, they were reluctant to continue the idea because they felt it would be a hassle for the parents. Another non-technical barrier is the problem of responding. The teachers complained that the response culture in the parent-student group was still not good. Parents prefer to ask questions through private networks rather than ask in groups. This situation sometimes makes it difficult for the teachers because they have to answer one by one.

Technical obstacles are related to internet connection problems and low signal that frequently occur. The Internet connection problems come from either the teachers or the students themselves. The problems start from less stable Wi-Fi, less quota, and the assumption that many people use Wi-Fi at home that may affect the signal strength. This condition follows the obstacles faced by students, of which $23 \%$ experienced an unstable internet network, $21 \%$ had a limited quota. These are the two significant aspects that interfere with the online learning process. This can affect the psychological condition of students (Jamaluddin et al., 2020).

The process of uploading learning video material takes quite a long time, and sometimes it can take up to an hour for the students to upload assignments. "Sometimes we have to upload it beforehand for quite long and schedule it so that when there is assignment it does not take time because my experience is like when we upload an assignment, we just want to upload it in the morning, and it is a long photo You cannot, it is like the upload is 
finished, isn't it, so it is usually handled before" $(\mathrm{G} 1,2021)$

Although it is a valuable experience because the teachers learn to use specific applications, it is unavoidable with the difficulties that accompany it. For example, G2 stated that it is not easy to make materials through the media. Apart from requiring more effort, they have to learn how to use the media itself. In addition, each media has its limitations.

For example, Zoom meetings can be pretty helpful because students can directly watch learning materials and see power points that the teacher has prepared. However, difficulties arise when some children cannot enter the Zoom room, first because of signal problems, then limited credits, and technical problems where both students and their parents have difficulties getting into Zoom because of their lack of knowledge. In addition, sometimes there are audio problems; in which students cannot hear the sound or vice versa. Such technical problem is distraction that makes the learning situation less conducive.

Not all students have sophisticated cellphones and can install specific applications, not to mention the memory problem that limits uploading videos or materials. The other problem is related to cellphone ownership. G2 shared her experience about one of her students who could not join Zoom because his brother used his cellphone also for Zoom. Meanwhile, a student could not participate in the lesson because he depended on his mother's cellphone, which was also used by his mother at the same time. Then after the class, several students told the teacher that they did not attend the 'virtual class' because their mothers brought their cellphones. On other occasions, when students who had a technical problem to solve assignment asked parents for help, the parents have no knowledge about this.

Technical barriers can be complex and lead to non-technical things, G1 said it was an 'unusual' experience when she had made every effort to create a learning video but it could not be downloaded or opened by her students. Then it became an issue among parents because it caused 'troublesome' to students. However, according to G1, she had no idea where the problem lies, be it is related to applications, connections or the type of mobile phone that cannot open specific applications due to the lack of memory.

\begin{abstract}
"When parents do not understand, they ask questions through WhatsApp, while at the same time, answering it can be pretty tricky. We, as teachers, understand the problem. However, when we try to give steps to parents to solve the problem, it is hard also because not all parents understand the technology and the use of learning applications" (G1, 2021).
\end{abstract}

For parents who pay no attention to such problems or have no knowledge of technology, the problems become obstacles in the learning process because they do not seem to 'help' their children to get school lessons and put the blame on teachers for the problem. The teachers feel they have done their utmost by creating learning videos to make the class as interactive as possible. This condition resulted in the teacher having to explain the parents one by one. In addition, G1 complained that sometimes parents wanted her to answer their questions quickly, even though she was overwhelmed by questions.

There has been an assumption on the part of the community that teachers did not do their jobs well apparently because parents taught their kids too much at home. The teachers were also rumored to have received sinecure. This assumption makes the relationship between teachers and parents less pleasant.

The difficulty related to parents is that not all of them want to get involved in the learning process. Some teachers believe that parents who seem indifferent are not willing to help even though they are working. For example, G1 complained that when she contacted parents in connection with their child's problems, they only said 'oh yes yes', but there was no change from the parents, and even they did not do anything.

"So, this is the outpouring of my heart as a teacher, under a condition like this, right? I want us to understand each other where no side benefits more. Yes, we are both facing difficulties during this pandemic, including teachers and parents. It will be great to work together like that where parents also have to be involved in this online learning" (G1, 2021). 
G3 said that parents had enthusiasm in guiding their children at home at the beginning of the semester in the past two years, but as time went by, the enthusiasm of parents decreased. G3 assumed this as people's fatigue in overcoming the difficulties faced by their children in online learning.

Another non-technical obstacle is when teachers cannot identify which students understand and which students do not. For example, there is a story from one teacher who said that he knew very well that the child had a weakness in capturing subject matter. However, during online learning, suddenly, the student seemed to understand the material very quickly. Moreover, conversely, during offline class, children are very fast in catching lessons, suddenly, they become hampered because they are challenged to catch it.

Teachers cannot measure their cognitive understanding directly. They do not know whether students are doing assignments, homework or tests assisted by other people at home or imitating their friends. Teachers cannot see which students understand the material and what difficulties the students face when watching learning materials through videos. Such things are difficult to identify directly Meanwhile, every teacher is required to provide assessments that are sometimes difficult to measure. Teachers receive many complaints from parents that when their children have difficulties doing their assignments, they immediately look for their answers through Google. So, there is an assumption that students can do their assignments by searching on Google, rather than learning from the textbooks provided or from the learning videos prepared by the teacher.

G3, a kindergarten teacher, admitted that she never knows the difficulties faced by her students because their parents assisted them in doing most of the assignments So this can be more appropriately referred to as the difficulty of parents, not their children. G3 also regretted that parents rarely talk about their children's cognitive difficulties at home, and G3 only received assignments that have been done. This is because of the limited communication media between teachers and parents. The obstacles faced by kindergarten teachers during the COVID-19 pandemic were classified into four indicators, namely communication barriers, learning methods, materials and costs and the use of technology (Agustin et al., 2020).

Apart from the assessment measured through understanding, character assessment is challenging to monitor. For example, G2 stated that character was a child's soft skill which is essential in life. However, the teachers cannot directly see how characters developdisciplinary issues and ethical issues.

The teachers realize that every student, especially elementary school student, has many distractions and must make more efforts to stay focused during class. For example, television, noise, and lack of supervision can distract and divert their attention to other things. "Some students opened other applications, while others played the games, ate, and slept" (G2, 2021).

G4 said that when she was having a Zoom meeting with her students, one of them was constantly being teased by his younger brother. As a result, the studen0t could not follow the lesson well. Since then, G4 made learning videos and used Zoom only for certain materials. G4 is a little different from the other teachers who feel that the obstacles or difficulties she experiences can still be overcome. She feels that parents should actively get involved in online learning so that the communication will be quite effective. The communication with the students is quite good. When using Zoom, the students are very active and responsive. G5, as a sixth-grade teacher, feels that she has a heavier burden because she has to prepare her students for transition to junior high school.

\section{Conclusion}

Almost one year and a half after the implementation of online learning, the number of COVID-19 cases has finally decreased. Schools began to apply for permits to hold face-to-face learning, which may soon be implemented for areas with level 3 public activity restrictions (PPKM) status or the 'orange' zone. However, concerns about new clusters in schools have sparked pros and cons over face-to-face learning. Even though teachers are worried about COVID-19 clusters in schools, they also want offline learning to be conducted immediately. This is relevant to the results of this research that reveal teachers' experiences during the pandemic and how the obstacles and challenges are. 
The experiences of these teachers are considered extraordinary. The experiences are divided into two categories, namely negative experiences and positive experiences. The negative experiences during online learning are related to confusion, culture shock, dissatisfaction, stress, fatigue, and overwhelm,. while the positive experiences are related to the ease of attending meetings simultaneously, so that they can follow them at home and gain new lessons, especially technology.

Barriers and challenges experienced by teachers in online learning during the pandemic are related to technical and non-technical barriers. The technical barriers are related to technical issues such as connections, credits, slow downloading or uploading of materials, and problems with cellphone, be it is not sophisticated, so it cannot use specific applications or cellphone memory has problems. Non-technical barriers and challenges are related to misunderstandings in interpersonal communication, especially between teachers, students and parents. Other non-technical problems are related to parental involvement, understanding and knowledge of various applications, and using them. In addition, teachers have difficulties measuring students' cognitive and ethical levels and external problems that interfere with students' concentration.

\section{References}

Agustin, M., Puspita, R. D., Nurinten, D., \& Nafiqoh, H. (2020). Tipikal Kendala Guru PAUD dalam Mengajar pada Masa Pandemi Covid 19 dan Implikasinya. Jurnal Obsesi : Jurnal Pendidikan Anak Usia Dini, 5(1), 334-345. https://doi.org/10.31004/OBSESI.V5I1.5 98

Anugrahana, A. (2020). Hambatan, Solusi dan Harapan: Pembelajaran Daring Selama Masa Pandemi Covid-19 Oleh Guru Sekolah Dasar. Scholaria: Jurnal Pendidikan Dan Kebudayaan, 10(3), 282-289.

https://doi.org/10.24246/J.JS.2020.V10.I 3.P282-289

Arnus, S. H. (2018). Computer Mediated Communication (Cmc),Pola Baru Berkomunikasi. Al-Munzir, 8(2), 275289.

https://doi.org/10.31332/AM.V8I2.744
Bajpai, A. (2021). Strong Teacher-Student Bond towards Effective Learning. 2021 JP International School Crafted. https://www.jpinternational.co.in/strongteacher-student-bond-towards-effectivelearning/

Cholily, Y. M., Putri, W. T., \& Kusgiarohmah, P. A. (2019). Pembelajaran Di Era Revolusi Industri 4.0 | Cholily | Seminar \& Conference Proceedings Of Umt. Seminar Nasional Penelitian Pendidikan Matematika (Snp2m) 2019 Umt. Http://Jurnal.Umt.Ac.Id/Index.Php/Cpu/ Article/View/1674

Collie, R. J. (2021). COVID-19 and Teachers' Somatic Burden, Stress, and Emotional Exhaustion: Examining the Role of Principal Leadership and Workplace Buoyancy:

Https://Doi.Org/10.1177/233285842098

6187, $7, \quad 233285842098618$. https://doi.org/10.1177/23328584209861 87

DeVito, J. A. (2009). Human Communication (Fifth). HarperCollinsPublishers.

Dewi, T. A. P., \& Sadjiarto, A. (2021). Pelaksanaan Pembelajaran Daring Pada Masa Pandemi Covid-19. Jurnal Basicedu, 5(4), 1909-1917. https://doi.org/10.31004/BASICEDU.V5 I4.1094

Emelia, R. I., \& Arina, M. (2021). Hambatan Komunikasi Dalam Pembelajaran Online Di Masa Pandemi Covid-19. Jurnal Akrab Juara, 6(2).

Fahmi, M. H. (2020). Komunikasi Synchronous Dan Asynchronous Dalam E-Learning Pada Masa Pandemic Covid19. Jurnal Nomosleca, 6(2). Https://Jurnal.Unmer.Ac.Id/Index.Php/N/ Article/View/4947

Hadi, R., Akbar, H. A., Mahvash, S., Alireza, K., Mohammadali, S., \& Nasim, B. (2012). Sampling In Qualitative Research: A Guide For Beginning (Vol. 10, Issue 339, Pp. 238-250). Annals Of Military And Health Sciences Research. Https://www.sid.ir/en/journal/ViewPaper .aspx?ID=333075

Harahap, S. A., Dimyati, \& Purwanta, E. (2021). Problematika Pembelajaran 
Daring dan Luring Anak Usia Dini bagi Guru dan Orang tua di Masa Pandemi Covid 19. Jurnal Obsesi: Jurnal Pendidikan Anak Usia Dini, 5(2).

Herliandry, L. D., Nurhasanah, N., Suban, M. E., \& Kuswanto, H. (2020). Pembelajaran Pada Masa Pandemi Covid-19. JTP Jurnal Teknologi Pendidikan, 22(1), 6570.

https://doi.org/10.21009/JTP.V22I1.1528 6

Hidayat, D. R., Rohaya, A., Nadine, F., \& Ramadhan, H. (2020). Kemandirian Belajar Peserta Didik Dalam Pembelajaran Daring Pada Masa Pandemi Covid -19. Perspektif Ilmu Pendidikan, 34(2), 147-154. https://doi.org/10.21009/PIP.342.9

Jamaluddin, D., Ratnasih, T., Gunawan, H., \& Paujiah, E. (2020). Pembelajaran daring masa pandemik Covid-19 pada calon guru: hambatan, solusi dan proyeksi. Digital Library UIN Dunan Djati.

kemdikbud. (2020). Kementerian Pendidikan dan Kebudayaan" Republik Indonesia. Https://Www.Kemdikbud.Go.Id/. https://www.kemdikbud.go.id/main/blog/ 2020/03/mendikbud-terbitkan-se-tentangpelaksanaan-pendidikan-dalam-masadarurat-covid19

Littlejohn, S. W., \& Foss, K. A. (2009). Encyclopedia of: Communication Theory. SAGE Publications Inc.

Marani, I. N., Subarkah, A., \& Wijayanto. Adi. (2020). The Use of Computer Mediated Communication (CMC) in Distance Learning During Covid-19 Pandemic: Pros and Cons. Advances in Social Science, Education and Humanities Research, 510.

Mastura, M., \& Santaria, R. (2020). Dampak Pandemi Covid-19 terhadap Proses Pengajaran Bagi Guru dan Siswa. Jurnal Studi Guru Dan Pembelajaran, 3(2), 289295.

https://doi.org/10.30605/JSGP.3.2.2020.2 93

Nassaji, H. (2015). Qualitative and descriptive research: Data type versus data analysis: Http://Dx.Doi.Org/10.1177/1362168815 572747, $\quad 19(2), \quad 129-132$. https://doi.org/10.1177/13621688155727 47

Perdana, P. P. (2021). Sekolah Tatap Muka Terbatas di Kota Bandung Digelar 8 September Halaman all - Kompas.com. Kompas.Com.

https://regional.kompas.com/read/2021/0 8/30/181720378/sekolah-tatap-mukaterbatas-di-kota-bandung-digelar-8september?page $=$ all

Purwanto, A., Pramono, R., Asbari, M., Hyun, C. C., Wijayanti, L. M., Putri, R. S., \& santoso, priyono B. (2020). Studi Eksploratif Dampak Pandemi COVID-19 Terhadap Proses Pembelajaran Online di Sekolah Dasar. EduPsyCouns: Journal of Education, Psychology and Counseling, 2(1), 1-12. https://ummaspul.ejournal.id/Edupsycouns/article/view/397

Survei PJJ TBM Lentera Pustaka, 67\% Siswa Terkendala Akses Internet Saat Belajar Online - Analisa - www.indonesiana.id. (n.d.). Retrieved September 14, 2021, from

https://www.indonesiana.id/read/141714/ survei-pjj-tbm-lentera-pustaka-67-siswaterkendala-akses-internet-saat-belajaronline

Susanti, R. (2021). Lebih dari 1.600 Sekolah di Bandung Siap Belajar Tatap Muka Terbatas Halaman all - Kompas.com. Kompas.Com.

https://regional.kompas.com/read/2021/0 8/25/163736078/lebih-dari-1600sekolah-di-bandung-siap-belajar-tatapmuka-terbatas?page $=$ all

TOctasya, T., \& Munawaroh, E. (2021). Level of academic stress for students of guidance and counseling at Semarang State University during the pandemic. ProGCouns: Journal of Professionals in Guidance and Counseling, 2(1). https://journal.uny.ac.id/index.php/progc ouns

Yunitasari, R., \& Hanifah, U. (2020). Pengaruh Pembelajaran Daring terhadap Minat Belajar Siswa pada Masa Covid 19. Edukatif: Jurnal Ilmu Pendidikan, 2(3), 232-243.

Https://Doi.Org/10.31004/Edukatif.V2i3. 142 
